\title{
SEGMENTASI DAN PERHITUNGAN SEL DARAH PUTIH MENGGUNAKAN OPERASI MORFOLOGI DAN TRANSFORMASI WATERSHED
}

\author{
Dwi Syamsuifin Alham*, Darlis Herumurti** \\ * Departemen Informatika, Univeristas Sembilan Belas November Kolaka \\ ** Departemen Informatika Institut Teknologi Sepuluh Nopember Surabaya \\ *** Departemen Informatika Institut Teknologi Sepuluh Nopember Surabaya \\ *dwi.syamsuifin@gmail.com , ${ }^{* *}$ darlis.herumurti@gmail.com,
}

\begin{abstract}
Perhitungan sel darah putih terkait dengan sistem kekebalan tubuh manusia karena bisa memberikan informasi tentang kondisi tubuh manusia seperti diagnosis penyakit, salah satunya leukimia. Penyakit ini ditandai dengan produksi sel darah putih berlebih yang menyebabkan fungsi normal darah menjadi terganggu dan dapat menyebabkan kematian. Untuk itu diperlukan deteksi dini penyakit ini, yang salah satunya dengan menganalisis populasi atau menghitung jumlah sel darah putih pada citra mikroskopis sel darah. Perlu dilakukan metode segmentasi yang tepat agar hasil perhitungan sel dapat maksimal. Metode Watershed merupakan metode yang dapat memisahkan objek yang saling berhimpit, tetapi memiliki kelemahan jika dalam suatu citra terdapat noise atau distribusi intensitas yang tidak merata. Oleh karena itu, untuk mengatasi masalah tersebut, maka ditambahkan operasi morfologi di awal untuk mengatasi adanya obyek yang tidak termasuk sel darah putih. Tahap terakhir adalah menghitung sel darah putih menggunakan standar objek yang dianggap sel darah putih normal berdasarkan ukuran roundness obyek. Pengujian dilakukan dengan menggunakan 35 citra dengan menggunakan nilai $\mathrm{SE}=20$ pada operasi morfologi opening. Hasilnya, akurasi perhitungan jumlah sel antara sistem dengan manual (ground truth) sebesar 97.67\%.
\end{abstract}

Keyword: Citra Mikroskopis, Segmentasi, Operasi Morfologi, Transformasi Watershed.

\section{Introduction}

Tubuh manusia membutuhkan sistem kekebalan tubuh untuk melawan bakteri, virus dan penyakit. Perhitungan sel darah putih dikatakan terkait erat dengan sistem kekebalan tubuh manusia karena jumlah sel darah putih bisa memberikan informasi tentang kondisi tubuh manusia seperti diagnosis penyakit, sebagai informasi keefektifan suatu terapi atau pengobatan dan mempunyai peranan penting pada sistem imun tubuh dalam melawan infeksi[1]. Salah satu diagnosis penyakit melalui informasi sel darah putih adalah leukemia. Leukimia atau kanker darah merupakan salah satu penyebab utama kematian di antara beberapa jenis kanker [2].

Banyak unsur yang ditemukan dalam pengamatan citra mikroskopis, salah satunya dapat mendeteksi penyakit leukemia. Penyakit ini ditandai produksi sel darah putih yang berlebih yang menyebabkan fungsi darah normal terganggu. Penyakit ini didefinisikan oleh [3] terdiri dari 4 (empat) jenis yaitu Leukemia limfotik akut atau acute lymphocytic leukemia (ALL), Leukemia mielogen akut atau acute myelogenous leukemia (AML), Leukemia limfotik kronis atau chronic lymphocytic leukemia (CLL) dan Leukemia mielogen kronis atau Chronic my-elogenous leukemia (CML).

Bidang medis menganalisis darah manusia dengan mikroskop yang dilakukan oleh ahli patologi dengan melakukan pengamatan pada bentuk, populasi dan jenis sel darah. Pada citra mikroskop leukimia, cara manual ini memakan waktu, membosankan dan rentan terhadap kesalahan, karena konsentrasi, lama pewarnaan, dan perbedaan suhu dapat menyebabkan warna pada citra mikroskopis menjadi beragam [4]. Selain cara manual ada juga yang menggunakan mesin penghitung hematologi otomatis. Akan tetapi dibutuhkan biaya yang sangat mahal untuk mendapatkan mesin tersebut [5]. Untuk itu penelitian tentang perhitungan sel darah putih terus dilakukan.

Tahap segmentasi pada sistem perhitungan sel darah putih sangat penting karena semakin akurat hasil segmentasi untuk memisahkan objek dan background, maka semakin banyak informasi yang bisa dibangun 
dan dikembangkan ke tahap perhitungan sel darah putih hingga identifikasi jenis penyakit leukemia. Penelitian segmentasi sel darah putih yang telah dilakukan diantaranya adalah menggunakan teknik klasterisasi, thresholding, operasi morfologi dan kombinasi dari beberapa metode [6].

Permasalahan teknik klasterisasi terletak pada penentuan inisialisasi titik pusat klaster awal, waktu lama dan terjebak dalam lokal optima [7] sedangkan metode thresholding tidak cocok untuk jenis citra yang mempunyai keragaman variasi warna. Operasi morfologi sangat tergantung pada struktur objek [8]. Akan tetapi operasi morfologi terbukti handal dalam menentukan region of interest (ROI) citra sel darah putih [9]. Diperlukan beberapa pengujian menggunakan beberapa nilai SE yang digunakan terhadap dataset sel darah putih agar bisa ditentukan nilai SE mana yang paling cocok untuk digunakan untuk menentukan ROI sehingga nilai tersebut bisa diberlakukan pada semua data dalam dataset.

Selain penentuan ROI, masalah lain adalah struktur objek pada citra mikroskopis memiliki kendala pada objek sel darah putih yang saling bersentuhan atau grup sel, yang menyebabkan sel darah putih normal memiliki bentuk menjadi tidak bulat sehingga perlu dilakukan pemisahan sel darah putih sebelum melakukan perhitungan jumlah sel dan pembersihan tepi pada setiap objek sel darah putih. Metode watershed merupakan metode yang mampu melakukan pemisahan sel yang saling bersentuhan dengan hasil yang dapat disesuikan dengan berbagai jenis ukuran objek dalam satu citra [10]. Hanya saja proses ini bisa menghasilkan hasil segmentasi yang berlebihan dari ukuran objek yang sebenarnya jika terdapat noise atau distribusi intensitas yang tidak merata [11]. Diperlukan kombinasi beberapa proses tambahan untuk menghindari kesalahan segmentasi ini.

Operasi morfologi opening bisa digunakan untuk menentukan ROI, dengan cara menghilangkan obyek yang tidak diinginkan seperti sel daraf merah. Metode Watershed bisa digunakan untuk memisahkan sel yang bersentuhan dan membantu dalam proses pembersihan sel darah putih yang berada di tepi citra. Penelitian ini mengusulkan kombinasi operasi morfologi dan metode Watershed untuk melakukan segmentasi. Hasil akhir watershed berupa objek sel darah putih yang terpisah akan dilabeli dan akan dihitung jumlahnya.

\section{Research Method}

Pada bagian ini, dijelaskan beberapa teori dasar pendukung penelitian, desain penelitian dan metode serta tahapan-tahapan penelitian yang dilakukan, seperti berikut :

\subsection{Dataset Citra Mikroskopis Leukemia}

Data citra mikroskopis sel darah putih yang digunakan merupakan citra mikroskopis yang berpenyakit leukemia. Proses pengambilan citra mikroskopis pada umumnya yaitu dimulai dari pengambilan sampel setetes darah. Sampel darah tersebut kemudian dikeringkan (smear) yang selanjutnya dilakukan proses staining atau pemberian zat warna. Langkah pewarnaan ini bertujuan mendapatkan visualisasi sel yang lebih baik dengan pengamatan menggunakan kamera mikroskop, karena sel darah merah dan sel darah putih mempunyai warna yang transparan. Perbedaan kondisi pada proses ini, seperti konsentrasi, suhu dan lama pewarnaan akan menyebabkan variasi informasi warna pada citra mikroskopis sel darah beragam. Data citra mikroskopis ini terdapat sel darah merah, sel darah putih, kepingan darah serta background.

Pada penelitian ini dataset yang digunakan yaitu citra mikroskopis leukemia berjumlah 35 citra dari berbagai jenis. Dimana diantaranya 25 citra jenis ALL diambil dari [12] dan 10 citra dengan jenis lain yang diambil dari berbagai sumber yang memiliki variasi warna beragam. Data citra mikroskopis ini terdapat sel darah merah, sel darah putih, kepingan darah serta background. Pada Gambar 1
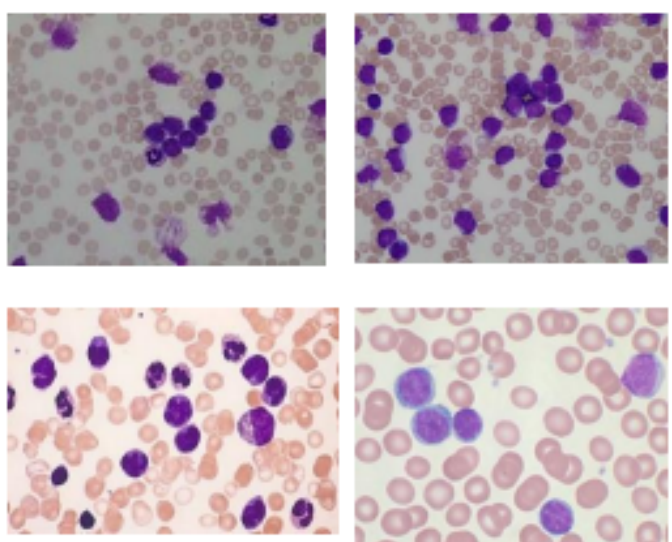

Figure 1. Citra sel darah putih mikroskopis leukemia. 


\subsection{Rancangan Sistem}

Rancangan proses utama sistem yang dibangun adalah menggunakan kombinasi operasi morfologi Opening dan metode Watershed untuk melakukan segmentasi. Sebelum operasi morfologi ada tahapan konversi HSV dan proses setelah metode Watershed yaitu tahapan perhitungan roundness untuk menampilkan hasil perhitungan jumlah keseluruhan sel dalam citra miksroskopis. Adapun gambaran umum sistem ditunjukkan pada Gambar 2.

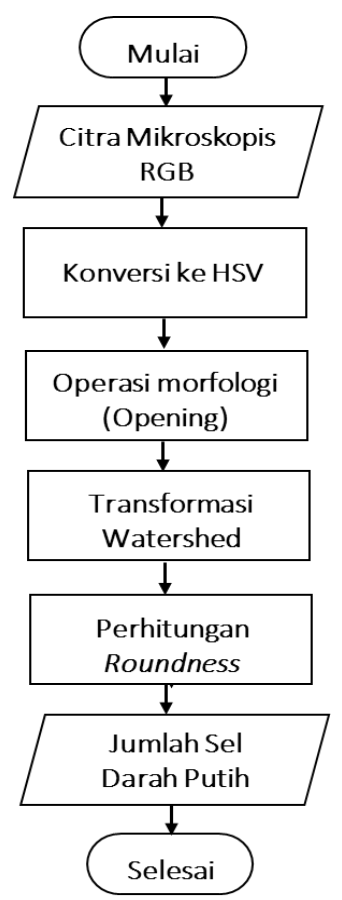

Gambar 2. Gambaran Umum Sistem

Pada Gambar 1 terlihat citra sel darah putih citra mikroskopis pada kanal Red, Green dan Blue (RGB) memiliki iluminasi pencahayaan dan variasi perawanaan yang beragam. Untuk itu perlu dilakukan mengurangi pengaruh pencahayaan dengan mengkonversi ruang warna dasar pada citra. [4] melakukan pengaruh pencahayaan dengan mengkonversi ruang warna RGB kedalam bentuk Hue, Saturation dan Value (HSV). Dimana karakteristik pokok dari warna tersebut adalah Hue merepresentasikan nilai warna sebenarnya, seperti merah, violet dan kuning dan digunakan menentukan kemerahan (redness), kehijauan (greeness), dan sebagainya. Saturation merepresentasikan chroma (kemurnian atau kekuatan warna) sedangkan Value merepresentasikan kecerahan dari warna. Nilainya berkisar antara 0-100 \%. Apabila nilainya 0 maka warnanya akan menjadi hitam, semakin besar nilai maka semakin cerah dan muncul variasi-variasi baru dari warna tersebut.

Citra mikroskopis yang berbentuk RGB akan dikonversi ke citra HSV (Hue, Saturation, Value) dengan tujuan mereduksi pengaruh pencahayaan yang tidak merata dan pengaruh variasi pewarnaan. Sel darah putih yang di dalamnya terdiri dari inti sel dan sitoplasma jika dilihat pada ruang warna Hue terlihat berwarna keabu-abuan dan sel darah merah terlihat lebih terang tetapi tidak terbentuk secara utuh. Akan tetapi jika dilihat pada ruang warna Saturation inti sel dari sel darah putih terlihat lebih terang namun sitoplasma terbentuk secara utuh dan sel darah merah hampir tidak terlihat jelas. Sedangkan jika dilihat pada ruang warna Value, sel darah putih dan sel darah merah masing-masing berwarna gelap.

Dari ketiga ruang warna pada HSV tersebut perlu dilakukan kombinasi ruang warna HSV. Tujuannya adalah agar objek sel darah putih yang di dalamnya terdiri dari inti sel dan sitoplasma dipastikan terambil secara menyeluruh. Kombinasi yang diambil adalah menggunakan kanal $\mathrm{H}$ dan kanal S yang digunakan dalam rekonstruksi citra untuk mendapatkan area sel darah putih [5]. Gambar 3 menunjukkan perbedaan hasil konversi menggunakan kanal HSV secara terpisah serta kombinasi kanal $\mathrm{H}$ dan S. 

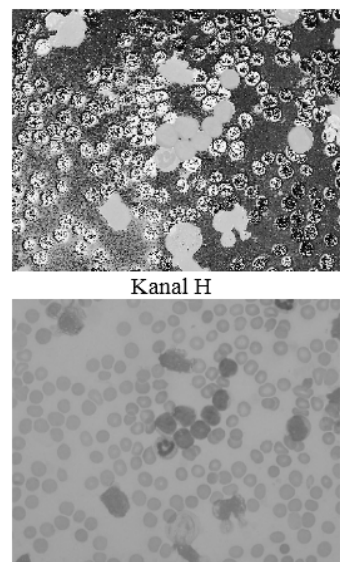

Kanal V
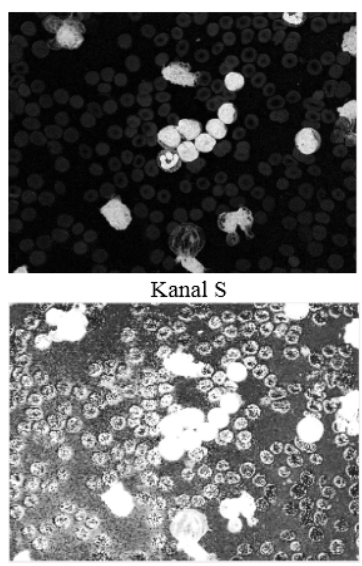

Kanal H + Kanal S

Gambar 3 Hasil Konversi HSV

Setelah dilakukan konversi HSV barulah dilakukan operasi morfologi opening. Proses ini bertujuan untuk menghilangkan artefak-artefak (sel darah merah) dari citra sel yang bisa dianggap sebagai sel darah putih. Sel darah merah memiliki bentuk yang kecil dan kadang nampak menempel pada sel darah putih. Karena beberapa variasi warna pada dataset maka dilakukan percobaan penggunaan SE (Structure Element) pada operasi morfologi opening untuk mendapatkan hasil yang bisa diberlakukan pada seluruh kondisi citra (35 citra) pada dataset. Hasilnya didapatkan penggunaan $\mathrm{SE}=20$ sebagai hasil terbaik. Hasil operasi morfologi opening ditunjukkan pada Gambar 4.

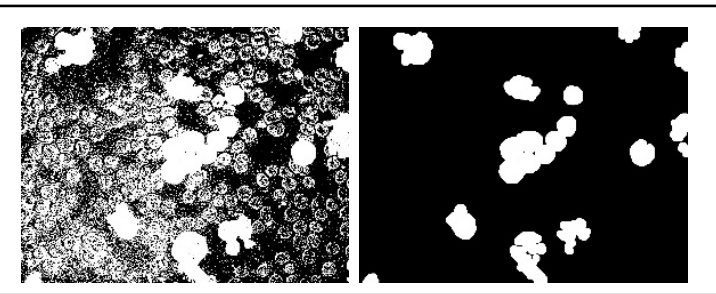

Gambar 4 Citra HSV, Kanal S + H (Kiri) dan Citra Hasil Morfologi Opening (Kanan)

Setelah operasi morfologi untuk menghapus artefak-artefak lain, maka diimplementasikan metode Watershed untuk memisahkan sel darah putih yang saling bersentuhan (grup sel) sehingga perhitungan jumlah sel dapat lebih maksimal. Gambar 5 menunjukkan hasil implementasi metode Watershed yang diwarnai agar memudahkan tampilan hasil segmentasi (secara visual).

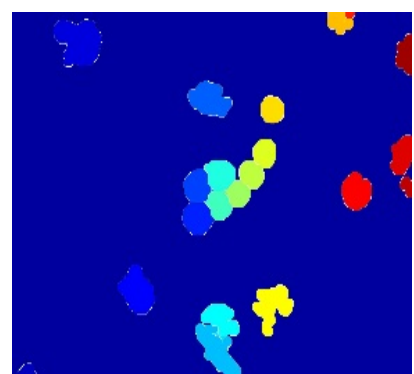

Gambar 5 Hasil Metode Watershed

Pada citra hasil Watershed nampak bahwa sel-sel yang saling bersentuhan sudah sudah bisa dibedakan dengan adanya garis tepi. Garis tepi ini juga membentuk sel yang berada di tepi citra. Pada umumnya sel darah putih memiliki bentuk yang bulat, akan tetapi pada citra mikroskopis leukemia memiliki sel darah putih abnormal dan sel darah putih yang berada di tepi citra (sel darah putih tidak utuh). Hal ini akan mengganggu proses perhitungaan sel dan identifikasi lain. Oleh karena itu, perlu dilakukan penghapusan sel darah putih abnormal dan sel darah putih yang berada di tepi citra. Penghapusan dapat dilakukan dengan memperhitungkan tingkat bulat menggunakan persamaan (1) pada objek dan penghapus citra yang berada ditepi citra.

$$
\text { Roundness }=\frac{4 * \pi * \text { area }}{\text { Perimeter }^{2}}
$$


Hasil citra yang telah dihapus sel darah putih abnormalnya dan sel yang berbatasan dengan tepinya ditunjukkan pada Gambar 6. Perhitungan sel darah putih akan dilakukan pada citra hasil penghapusan objek yang ditunjukkan pada Gambar 6.

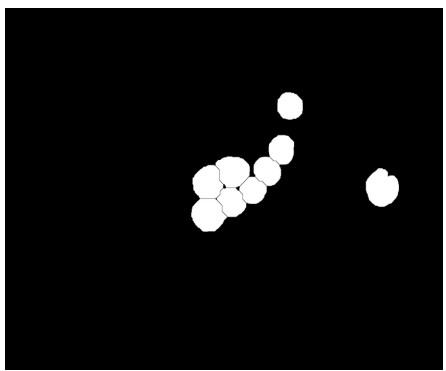

Gambar 6 Hasil Penghapusan Obyek yang Tidak Termasuk Sel Darah Putih Normal

\subsection{Operasi Morfologi}

Tujuan operasi morfologi adalah untuk memperoleh informasi mengenai bentuk dari suatu citra dengan mengatur bentuk dan ukuran suatu structuring element. Dalam penggunaannya, morfologi selalu melibatkan sebuah citra dengan komponen I (citra) dan elemen penyusun E (structuring element). Morfologi mempunyai dua operator dasar, yaitu Dilasi (dilation) dan Erosi (erosion) yang biasa digunakan untuk mengekstrak komponen yang diinginkan dalam sebuah citra. Berdasarkan dua operator tersebut, dapat diturunkan dua operator lainnya yang berguna untuk menghaluskan batas subinterval komponen yang telah diekstrak, yaitu opening dan closing.

Dilasi merupakan penambahan piksel pada batas antar objek dalam suatu citra digital. Atau secara rinci dilasi merupakan suatu proses menambahkan piksel pada batasan dari objek dalam suatu gambar sehingga nantinya apabila dilakukan operasi ini maka gambar hasilnya lebih besar ukurannya dibandingkan dengan gambar aslinya. Dilasi dapat ditulis dengan menggunakan persamaan (2).

$$
A \oplus B=\left\{z \mid(\widehat{B})_{z} \cap A \neq \emptyset\right\}
$$

Dimana $\emptyset$ adalah empty set dan B adalah struktur elemen dengan kata lain, dilasi A oleh B adalah set yang terdiri dari semua lokasi origin struktur elemen dimana refleksi dan translasi dari B setidaknya saling meliputi A.

Erosi merupakan kebalikkan dari dilasi. Proses ini akan membuat ukuran sebuah citra menjadi lebih kecil. Berbeda dengan dilasi, apabila erosi dilakukan maka yang dikerjakan adalah memindahkan piksel pada batasan-batasan objek yang akan di erosi. Jumlah dari piksel yang ditambah atau dihilangkan bergantung pada ukuran dan bentuk dari struktur elemen yang digunakan untuk memproses citra tersebut. Erosi memiliki persamaan yang ditunjukkan pada persamaan (3). Erosi A oleh B adalah suatu set dari semua lokasi origin stuktur elemen, dimana translasi dari B tidah mengandung background A.

$$
A \ominus B=\left\{z \mid(B)_{z} \cap A^{c} \neq \emptyset\right\}
$$

Opening merupakan kombinasi proses dimana suatu citra digital dikenai operasi erosi dilanjutkan dengan dilasi. Operasi opening pada citra mempunyai efek memperhalus batas-batas objek, memisahkan objekobjek yang sebelumnya bergandengan, dan menghilangkan objek-objek yang lebih kecil daripada ukuran strukturing. Dimana A॰B merupakan operasi erosi yang diikuti oleh dilasi. Operasi closing ditunjukkan pada Persamaan (4)

$$
A \circ B=(A \ominus B) \oplus B
$$

\subsection{Metode Watershed}

Algoritma Watershed ini dikembangkan oleh [13]. Pertama kali, buat array $M 1, M 2, M 3, \ldots ., M R$ dari koordinat titik daerah dengan nilai minimum pada gambar $g(x, y)$. Kemudian dibuat $C(M i)$ yaitu kumpulan koordinat pada catchment basin yang memiliki hubungan dengan daerah minimum $M i$. Terakhir buat $T[n]$, kumpulan koordinat $(s, t)$ di mana $g(s, t)<n$, sehingga dapat didefinisikan persamaan (5).

$$
T[n]=\{(s, t) \mid g(s, t)<n\}
$$

Kemudian buat $C_{n}\left(M_{i}\right)$ menjadi kumpulan koordinat titik pada catchment basin 
yang berhubungan dengan daerah minimum $M_{i}$ yang diisi pada tahap $n$ dengan persamaan (6) menjadi persamaan (7).

$$
\begin{aligned}
& C_{n}\left(M_{i}\right)=C\left(M_{i}\right) \cap T[n] \\
& C_{n}\left(M_{i}\right)=\left\{\begin{array}{r}
1 \text { jika }(x, y) \in C\left(M_{i}\right) \text { dan } \\
(x, y) \in T[n] \\
0 \text { selain itu }
\end{array}\right. \\
& C(n)=\bigcup_{i=1}^{h} C_{n}\left(M_{i}\right) \\
& C(\max +1)=\bigcup_{i=1}^{h} C_{n}\left(M_{i}\right)
\end{aligned}
$$

$C[n-1]$ adalah subset dari $C[n]$. Dari persamaan (5) dan (8), $C[n]$ adalah subset dari $T[n]$ maka $C[n-1]$ adalah subset dari $T[n]$. Dari sini didapatkan bahwa tiap komponen yang terhubung dari $C[n-1]$ memiliki 1 komponen yang terhubung dari $T[n]$. Jika $\mathrm{Q}$ adalah kumpulan komponen yang terhubung dalam $T[n]$, maka untuk tiap komponen yang terhubung $q \in Q[n]$ maka ada 3 kemungkinan:

a. $q \cap C[n-1]$ adalah kosong.

b. $q \cap C[n-1]$ mengandung 1 komponen yang terhubung dari $C[n-1]$.

c. $C[n-1]$ mengandung lebih dari 1 komponen yang terhubung dari $C[n-1]$.

Jika kondisi $c$ terjadi maka pengisian akan menyebabkan 2 daerah menjadi 1 , maka titik pada $C[n-$ 1] menjadi milik dam atau watershed line.

\section{Analisis Hasil dan Pembahasan}

Pada penelitian ini tahapan implementasi dan pengujian dilakukan dengan menggunakan spesifikasi sistem yang terdiri dari perangkat keras dan perangkat lunak. Perangkat keras yang digunakan yaitu Central Processing Unit Amd A8, 2 GHz dan RAM 8 GB sedangkan perangkat lunak yang digunakan adalah windows 1064 bit dan matlab R2015a.

Dataset yang digunakan untuk melakukan uji coba yaitu citra mikroskopis leukemia berjumlah 35 citra dari berbagai jenis. Dimana diantaranya 25 citra jenis Lymphocytic leukemia, salah satu jenis leukimia yang diambil dari penelitian dan 10 citra dengan jenis lain yang diambil dari berbagai sumber yang memiliki variasi warna beragam.

Sebelum melakukan uji coba perhitungan, dilakukan dulu uji coba penetapan nilai SE pada operasi Morfologi Opening pada semua data citra. Nilai SE yang dicoba adalah 10, 15, 20 dan 25. Setelah mengamati hasil uji coba nilai SE pada semua data, ditetapkan nilai $\mathrm{SE}=20$ sebagai hasil terbaik yang dapat menampilkan bentuk sel darah putih lebih jelas dan membuat kabur bagian obyek yang bukan sel darah putih. Gambar 7 menunjukkan contoh citra perbandingan implementasi dengan menggunakan beberapa nilai SE.

Setelah itu proses selanjutnya yaitu menggunakan operasi morfologi opening. Konsep umum dari morfologi adalah membutuhkan struktur elemen sebagai parameter untuk menentukan daerah objek. Karena tidak adanya aturan baku dalam menentukan parameter pada struktur elemen sehingga dibutuhkan pengujian parameter untuk ditetapkan sebagai parameter khusus yang akan digunakan. Pemilihan parameter yang diharuskan dapat mewakili keseluruhan dataset yang akan digunakan. Dilihat dari jenis citra mikroskopis sel darah putih yang memiliki variasi warna yang beragam. Pada penelitian ini menggunakan 4 sampel citra untuk pengujian seperti pada Gambar 7 yang akan mewakili seluruh dataset yang akan digunakan 


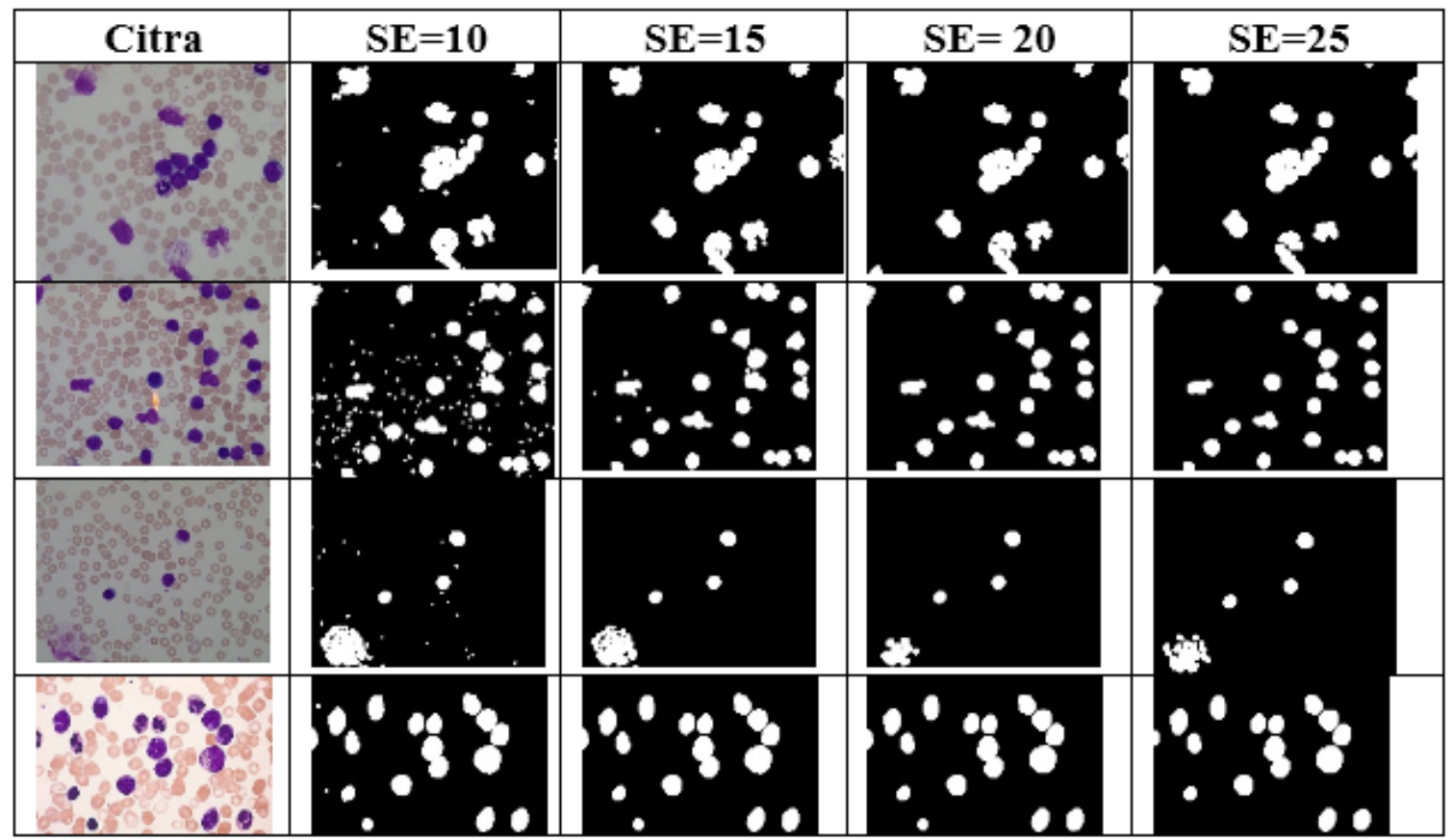

Gambar 7. Perbandingan Implementasi Nilai SE pada Beberapa Citra

Dari beberapa pengujian yang telah dilakukan pada penelitian ini menggunakan parameter pembanding sebagai acuan untuk mengambil kesimpulan dari parameter yang akan digunakan. Jika dilihat pada Gambar 7 parameter yang tepat yang akan digunakan dalam penelitian ini adalah dengan menggunakan struktur elemen sama dengan 20 ( $\mathrm{SE}=20)$, karena sudah dapat mengambil seluruh komponen sel darah putih. Hal ini dapat dilihat pada Gambar 7 kolom $4(\mathrm{SE}=20)$ dimana komponen sel darah putih robust terhadap noise jika dibandingkan dengan menggunakan struktur elemen yang lain seperti $\mathrm{SE}=10, \mathrm{SE}=15$ dan $\mathrm{SE}=25$.

Dari hasil uji coba yang telah dilakukan terhadap dataset sejumlah 35 citra leukimia dapat ditunjukkan pada Tabel 1. Pada Tabel 1 menunjukkan hasil pebandingan antara hasil segmentasi oleh ahli leukimia dengan sistem yang di usulkan. Correct merupakan jumlah sel darah putih yang tersegmentasi. Under merupakan jumlah kekurangan dari jumlah sel darah yang tersegmentasi, sedangkan Over merupakan kelebihan dari jumlah sel darah putih yang tersegmentasi. Dari total 35 citra sel leukimia yang telah di uji coba menunjukkan bahwa ada 29 sel leukimia yang tersegmentasi dengan benar dan 6 citra sel leukimia yang tidak tersegmentasi dengan benar, seperti citra sel leukimia No. 3, 5, 8, 28, 31, 34 seperti yang ditunjukkan pada Tabel 1. Hasil uji coba pada citra sel leukimia No. 3 menunjukkan bahwa terdapat Over = 1 yang artinya jumlah sel leukemia yang ditetapkan oleh ahli adalah 18, sedangkan sistem yang diusulkan mendeteksi jumlah sel leukimia adalah 19.

Tabel 1. Perbandingan error perhitungan yang Dilakukan oleh Sistem

\begin{tabular}{|c|c|c|c|c|c|c|c|c|c|}
\hline \multirow{2}{*}{$\begin{array}{c}\text { Citra } \\
\text { ke- }\end{array}$} & \multirow{2}{*}{ Ahli } & \multicolumn{3}{|c|}{ Sistem } & \multirow{2}{*}{$\begin{array}{c}\text { Citra } \\
\text { ke- }\end{array}$} & \multirow{2}{*}{ Ahli } & \multicolumn{3}{|c|}{ Sistem } \\
\hline & & Correct & Under & Over & & & Correct & Under & Over \\
\hline 1 & 9 & 9 & 0 & 0 & 19 & 2 & 2 & 0 & 0 \\
\hline 2 & 7 & 7 & 0 & 0 & 20 & 3 & 3 & 0 & 0 \\
\hline 3 & 18 & 19 & 0 & 1 & 21 & 2 & 2 & 0 & 0 \\
\hline 4 & 7 & 7 & 0 & 0 & 22 & 7 & 7 & 0 & 0 \\
\hline 5 & 17 & 16 & 1 & 0 & 23 & 2 & 2 & 0 & 0 \\
\hline 6 & 16 & 16 & 0 & 0 & 24 & 9 & 9 & 0 & 0 \\
\hline 7 & 15 & 15 & 0 & 0 & 25 & 5 & 5 & 0 & 0 \\
\hline 8 & 17 & 18 & 0 & 1 & 26 & 10 & 10 & 0 & 0 \\
\hline 9 & 16 & 16 & 0 & 0 & 27 & 3 & 3 & 0 & 0 \\
\hline 10 & 3 & 3 & 0 & 0 & 28 & 16 & 14 & 2 & 0 \\
\hline 11 & 2 & 2 & 0 & 0 & 29 & 3 & 3 & 0 & 0 \\
\hline
\end{tabular}




\begin{tabular}{cccccccccc}
12 & 3 & 3 & 0 & 0 & 30 & 7 & 7 & 0 & 0 \\
13 & 5 & 5 & 0 & 0 & 31 & 15 & 14 & 1 & 0 \\
14 & 7 & 7 & 0 & 0 & 32 & 2 & 2 & 0 & 0 \\
15 & 4 & 4 & 0 & 0 & 33 & 5 & 5 & 0 & 0 \\
16 & 3 & 3 & 0 & 0 & 34 & 4 & 3 & 1 & 0 \\
17 & 5 & 5 & 0 & 0 & 35 & 5 & 5 & 0 & 0 \\
18 & 3 & 3 & 0 & 0 & & & & & \\
\hline
\end{tabular}

Akurasi hasil segmentasi dihitung dengan membandingkan hasil perhitungan menggunakan metode yang diusulkan dan perhitungan manual (ground truth) yang sudah diketahui sebelumnya pada informasi data citra. Tabel 1 menunjukkan hasil perbandingan perhitungan dan jumlah error antara perhitungan manual dengan metode yang diusulkan yaitu kombinasi Operasi Morfologi dan Transformasi Watershed untuk tiap citra uji. Berdasarkan hasil pengujian dari metode yang usulkan, terlihat pada Tabel 1 memiliki tingkat akurasi yang tinggi dengan mencapai $97.67 \%$.

\section{Conclusion}

Pada penelitian ini diusulkan sistem segmentasi dan perhitungan sel darah putih menggunakan operasi morfologi dan transformasi watershed. Tujuan perancangan sistem dari penelitian ini adalah meningkatkan hasil segmentasi dan akurasi citra mikroskopis sel darah putih, sehingga dapat memperbanyak informasi fitur untuk pendeteksian penyakit leukemia. Uji coba telah dilakukan dengan menggunakan dataset citra mikroskopis leukemia berjumlah 35 citra dari berbagai jenis. Berdasarkan hasil pengujian yang telah dilakukan maka dapat disimpulkan bahwa segmentasi menggunakan operasi morfologi opening dengan nilai SE=20 yang didapatkan dari pengujian dan pengamatan dengan hasil terbaik secara visual dan dengan nilai SE tersebut didapatkan Akurasi perhitungan sel darah putih adalah 97.67\%.

Adapun saran untuk penelitian selanjutnya adalah perlu adanya penelitian lebih lanjut pada proses penentuan ROI menggunakan operasi morfologi, karena ada beberapa sitoplasma yang hilang akibat dari proses ini yang disebabkan struktur elemen yang tidak merata untuk seluruh citra.

\section{Acknowledgements}

Penulis mengucapkan terima kasih kepada semua pihaak terkai dalam referensi jurnal ini yang telah memberikan masukkan dari segi teori dan pemahaman terhadap penelitian ini.

\section{References}

[1] C. Zhang et al., "White blood cell segmentation by color-space-based k-means clustering," Sensors (Switzerland), vol. 14, no. 9, pp. 16128-16147, 2014.

[2] S. Sarimuddin, C. Fatichah, and N. Suciati, "Inisialisasi Klaster Berbasis Varian Maksimum Ternormalisasi Pada Fuzzy C-Means Untuk Segmentasi Sel Darah Putih Pada Citra Mikroskopis Leukemia," Inspir. J. Teknol. Inf. dan Komun., vol. 7, no. 1, pp. 32-41, 2017.

[3] F. Thol, R. F. Schlenk, M. Heuser, and A. Ganser, "How I treat refractory and early relapsed acute myeloid leukemia," Blood, vol. 126, no. 3, pp. 319-327, 2015.

[4] D. Huang, K. Hung, and Y. Chan, "A computer assisted method for leukocyte nucleus segmentation and recognition in blood smear images," J. Syst. Softw., vol. 85, no. 9, pp. 2104-2118, 2012.

[5] S. Nabilah, M. Safuan, M. R. Tomari, W. Nurshazwani, and W. Zakaria, "White blood cell counting analysis of blood smear images using various segmentation strategies White blood cell ( WBC ) counting analysis in blood smear images using various color segmentation methods," Measurement, vol. 116, no. September, pp. 543-555, 2017.

[6] T. Chen, Y. Chen, and S. Chien, "Fast image segmentation based on K-Means clustering with histograms in HSV color space," 2008 IEEE 10th Work. Multimed. Signal Process., pp. 322-325, 2008.

[7] W. Alomoush and S. Abdullah, "MRI brain segmentation via hybrid firefly search algorithm," J. Theor. Appl. Inf. Technol., vol. 61, pp. 73-90, 2014.

[8] H. T. Madhloom and S. A. Kareem, "An Image Processing Application for the Localization and Segmentation of Lymphoblast Cell Using Peripheral Blood Images," Springer Sci., vol. 36, pp. 2149-2158, 2012.

[9] A. Harto and C. Fatichah, "Segmentasi Dan Pemisahan Sel Darah Putih Bersentuhan Menggunakan K-Means Dan Hierarchical Clustering Analysis Pada Citra Leukemia Myeloid Akut," JUTI J. Ilm. Teknol. Inf., vol. 15, no. 2, p. 162, 2017.

[10] H. Yang and N. Ahuja, "Automatic segmentation of granular objects in images: Combining local density clustering and gradient-barrier watershed," Pattern Recognit., vol. 47, no. 6, pp. 2266-2279, 2014.

[11] U. Salamah et al., "Segmentation of Malaria Parasite Candidate from Thickblood Smear Microscopic Images using Watershed and Adaptive Thresholding," J. Telecommun. Electron. Comput. Eng., vol. 10, no. 2, pp. 113- 
117.

[12] I. I. Conference and I. Processing, “ALL-IDB : THE ACUTE LYMPHOBLASTIC LEUKEMIA IMAGE DATABASE FOR IMAGE PROCESSING Ruggero Donida Labati , Vincenzo Piuri, Fabio Scotti Università degli Studi di Milano, Department of Information Technology ," Ieee Int. Conf. Image Process., pp. 2089-2092, 2011.

[13] "Vincent Soille IEEE Trans PAMI v13n6 1991.pdf.”. 